\title{
Silica Dust as an Additive in Concrete with Proven Impact on Human Health
}

\author{
Magdalena Penkała1, Pawel Ogrodnik ${ }^{2 *}$, Wioletta Rogula-Kozłowska ${ }^{2}$ \\ ${ }^{1}$ The State School of Higher Education, Chełm, Poland \\ ${ }^{2}$ The Main School of Fire Service, Faculty of Fire Safety Engineering, Warsaw, Poland
}

Received: 3 July 2018

Accepted: 27 October 2018

\begin{abstract}
Concrete is an extremely important factor for shaping today's infrastructure. However, it must be replaced or repaired over time. The various methods used to remove, repair or change existing concrete structures into new ones can globally release large amounts of dust into the air. Taking into account the fact that the crystalline silica in the form of quartz is the main component of silica fume added to concrete, dust in the air produced during construction, maintenance or renovation works may have properties that will increase not only the risk of morbidity of workers (e.g., silicosis), but also the risk of excessive contamination - by crystalline silica - of air and soils around areas where such work is carried out. This paper presents the properties of silica, which determine its presence and interactions in the environment. It has been shown that so far, the health exposure to silica was studied mainly in groups of miners. Most likely, the widespread use of silica in the construction industry and, above all, in the construction and renovation of the dynamically developing network of roads and motorways results in an increase in the amount of silica in fine particles of particulate matter. Therefore, it seems important to undertake new research to determine the amount of silica in the environment (mainly in fine particulate matter) in various areas and to link these data with industrial and construction activity in these areas.
\end{abstract}

Keywords: fine particles, crystalline silica exposure, road dust, elemental composition, road construction, road surface or pavement

\section{Introduction}

The negative effect of the industrialization of the economy is undoubtedly the increase in the production of industrial waste. The safe utilization of this waste is a major problem, both due to restrictions on storage locations and strict environmental standards related to the quantity and quality of generated waste. The growing

*e-mail: pogrodnik@sgsp.edu.pl demand for raw materials for the production of building materials led to the development of research on the possibility of using some industrial waste in the cement industry, e.g., blast furnace slag, fly ash and silica dust [1-2]. Due to increased environmental awareness and the potentially dangerous effects of industrial by-product storage, adding silica dust to concrete has become an attractive alternative to its storage [3-4].

Over the past two decades, silica fumes have gained acceptance as a pozzolan mineral admixture in concrete [5]. In the 1950s in northern European countries the first studies on the use of silica dust in concrete were 


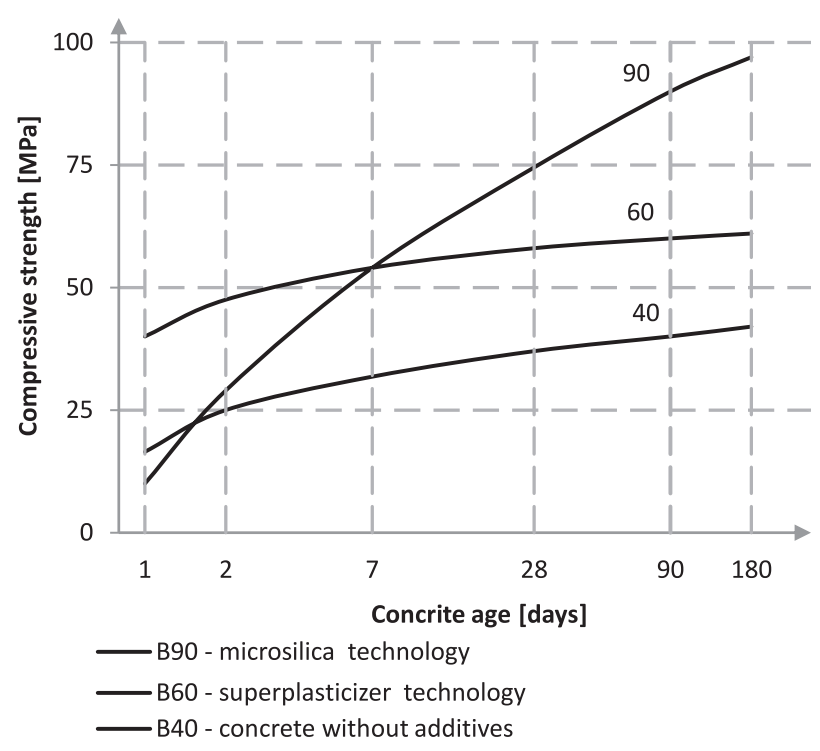

Fig. 1. Variation in time of concrete compressive strength for various concrete technologies (based on [9]).

carried out and they consisted of adding this material or by partially replacing Portland cement [6-7]. It was found that the compressive strength of concrete samples consisting of Portland cement with the addition of silica dust is significantly higher than the strength of samples without the addition of such dusts [8-10] (Fig. 1).

The proportion of microsilica in the concrete is determined individually, depending on what physical properties are critical (e.g., increased compression, bending and stretching strength) and what element will be made of it (e.g., bridges, tunnels, motorways, runways). The amount of binder (cement $+\mathrm{k} \times$ additive) should not be less than the minimum cement content required due to the appropriate exposure class [11] (Table 1).

The concept of coefficient $\mathrm{k}$ is a recommended concept. It is based on a comparison of durability (or strength as a substitute for durability) of the reference concrete with cement "A" and concrete in which part of cement "A" has been replaced with an additive, taking into account the water/cement coefficient and additive content. In the case of type II additives, the PN-EN 13263-1: 2010 standard introduces the concept of coefficient $\mathrm{k}$, which allows us to include additives in the composition of concretes by replacing the term "coefficient water/cement" with the term "coefficient water/(cement $+\mathrm{k} \times$ additive)" [11, 13].

Due to its high silica content and very fine particle size, silica dust is a highly effective pozzolan. Amorphous silica reacts very rapidly with calcium hydroxide released in the hydration of silicates contained in Portland cement (so-called pozzolanic reaction), creating a homogeneous, durable product that acts as a binder in concrete. A compact and impermeable gel of hydrated calcium silicates (so-called C-S-H phase) is formed. The very fine grains of silica fill the spaces between the cement grains in the leaven/concrete and then the structure is sealed (concentrated). The matrix of hydration products closely adhering to the remains of unhydrated cement grains and showing negligible porosity is characterized by a rapid build-up of strength [14-15].

The obtained cement-silica mixture produces a bond matrix that has a dense microscopic pore structure, low permeability and is more resistant to degradation caused by acid rain, seawater, deicing salts of roads and pavements, and cycles of freezing and thawing [16]. Abrasion resistance is an important long-term requirement for all concrete surfaces exposed to pedestrian and vehicle traffic, or wind and water in hydraulic construction [5]. The abrasion of the surface layer has the components of materials and their proportions, design, performance, hardening and degree of exposure to devastating/unfavorable conditions [17].

In recent years, due to the development of highperformance concrete technology with a low water/ binder coefficient (water/(cement $+\mathrm{k} \times$ additive), as well as the emergence of a new generation of chemical admixtures, the ability to control the properties of a concrete mixture containing silica dust with the help of suitable superplasticizers have significantly expanded

Table 1. Rules for the use of silica dust in accordance with PN-EN 206:2014 [12].

\begin{tabular}{|c|c|}
\hline \multicolumn{2}{|c|}{ Silica dust of class $1^{1)}$ according to PN-EN 13263-1:2010 } \\
\hline $\begin{array}{c}\text { The maximum content } \\
\text { of the additive in concrete }{ }^{2)}\end{array}$ & Silica dust/cement $\leq 0.11$ \\
\hline Value $\mathrm{k}^{3)}$ & $\begin{array}{c}\text { For cement CEM I i CEM II } / \mathrm{A}: \mathrm{k}^{3)}=2.0 \text { for w/c } \leq, 45 \\
\mathrm{k}^{3)}=2.0 \text { for w/c }>0,45 \text { with the exception of exposure classes XC and XF, for which } \mathrm{k}=1.0\end{array}$ \\
\hline The minimum cement content & min. cement content should not be reduced by more than $30 \mathrm{~kg} / \mathrm{m}^{3}$ \\
\hline
\end{tabular}

1) In the case of class 2 silica dust, shall be applied the provisions in force at the place of concrete using.

2) In the case of a higher content of the additive in concrete, this excess should not be taken into account when calculating the coef-

ficient $\mathrm{w} /(\mathrm{c}+\mathrm{kxd})$.

3) With the exception of cements with addition of silica dust.

w - water

$\mathrm{c}$ - cement

$\mathrm{XC}$ - corrosion due to carbonisation

$\mathrm{XF}$ - aggressive impact of freezing / thawing (exposure class according to standard EN 206-1) 
[18-19]. Technology of high value concretes determines the material with high mechanical strength $(R \geq 60 \mathrm{MPa})$ and high durability. Microsilica is also a component of unconventional structural concretes with special mechanical properties. There is, e.g., concrete made with the addition of powders with high chemical reactivity in the leaven environment or fibre-reinforced concrete. These materials must contain a very finely dispersed component in order to seal the microstructure, and this property is characterized by microsilica [20-22].

\section{Silica Dust}

Silica dust is a very finely divided amorphous silicon oxide [16]. European Standard PN-EN 206:2014 defines a concrete additive as a finely divided material used to improve properties or achieve special properties, and distinguishes two types of additives:

- Type I - almost inert additives: fillers and pigments.

- Type II - pozzolanic or with poor hydraulic performance.

Only additives with a fixed suitability should be used for concrete. It is assumed as type II additives, fly ash, silica dust and ground granulated blast furnace slag [12]. Table 2 summarizes the chemical composition as well as physical and standard requirements for silica dust.

In the literature we can find different names for this material: silica fumes, silica dust, microsilica, condensed silica fume or silica powder [23]. The most suitable term is condensed silica dust. It is a byproduct in metallurgical processes and more specifically from the production of silicon metal and ferro-silicon alloys $[10,24]$. Particles of partially reduced quartz evaporate as $\mathrm{SiO}$ and are oxidized to $\mathrm{SiO}_{2}$ as a result of contact with oxygen in the cooler part of the furnace. There is formed an amorphous form of silicon, whose formation can be described by the following reactions [9]:

Table 2. Requirements for the properties of silica dust (PNEN-13263-1:2010) [10-11].

\begin{tabular}{|c|c|c|}
\hline Property & \multicolumn{2}{|c|}{ Requirements } \\
\hline $\mathrm{SiO}_{2}$ & cat. $1 \geq 85.0 \%$ & cat. $2 \geq 80.0 \%$ \\
\hline Elemental silicon & \multicolumn{2}{|c|}{$\leq 0.4 \%$} \\
\hline Free $\mathrm{CaO}$ & \multicolumn{2}{|c|}{$\leq 1.0 \%$} \\
\hline Sulfur as $\mathrm{SO}_{3}$ & \multicolumn{2}{|c|}{$\leq 2.0 \%$} \\
\hline $\begin{array}{l}\text { Total content of alcalis } \\
\text { based on } \mathrm{Na}_{2} \mathrm{O}\end{array}$ & \multicolumn{2}{|c|}{ declared value } \\
\hline Chlorides & \multicolumn{2}{|c|}{$\leq 0.3 \%$} \\
\hline Loss on ignition & \multicolumn{2}{|c|}{$\leq 4.0 \%$} \\
\hline Surface area & \multicolumn{2}{|c|}{$35.0 \mathrm{~m}^{2} / \mathrm{g}>\mathrm{x}>15.0 \mathrm{~m}^{2} / \mathrm{g}^{-1}$} \\
\hline $\begin{array}{l}\text { Component content in } \\
\text { suspension }\end{array}$ & \multicolumn{2}{|c|}{$\begin{array}{l} \pm 2 \% \text { the value declared by } \\
\text { producer }\end{array}$} \\
\hline Activity index & \multicolumn{2}{|c|}{$100 \%$ up to 28 days } \\
\hline
\end{tabular}

$$
\begin{gathered}
\mathrm{SiO}_{2}+\mathrm{C} \rightarrow \mathrm{SiO}+\mathrm{CO} \\
2 \mathrm{SiO} \rightarrow \mathrm{Si}+\mathrm{SiO}_{2} \\
3 \mathrm{SiO}+\mathrm{CO} \rightarrow \mathrm{SiC}+2 \mathrm{SiO}_{2}
\end{gathered}
$$

During the production process at the exhaust of the flue-gases there are mounted filters catching solid particles, and with them also condensing pairs of silica. They have a high content of silicon dioxide $\mathrm{SiO}_{2}$ (85-97\%) and consist of very fine spherical, glassy particles with a specific surface area of about $20000 \mathrm{~m}^{2} / \mathrm{kg}[3,16]$.

The amount of $\mathrm{SiO}_{2}$ in dust increases proportionally with the increase of silicon in alloy and, e.g., for ferrosilicon alloy containing $50 \%$ or $75 \%$ of silicon - we have respectively $61 \div 77 \%$, or $84 \div 88 \%$ silica in dusts, and for silicon metal up to $98 \%$ of silica in dust [9].

Silica dust is produced in many countries, including Canada, Egypt and Norway. In Poland, silica dust is produced only at Łaziska steelworks $\left(85-95 \% \mathrm{SiO}_{2}\right)$ as a by-product in the production of ferro-silicon. In the production of each ton of ferro-silicon alloy, about 300 $\mathrm{kg}$ of dust are produced simultaneously. The chemical composition of silica dust varies depending on the type of alloy or metal from which it was made [10, 25]. Table 3 summarizes the chemical composition of silica fume from silicon furnaces in Norway, Canada and Poland.

The basic forms of the available microsilica, which are adapted for transportation, storage and dosing to concrete:

a) Dry silica dust of an aerial colloid nature in which the silica particles are the dispersed phase and the air-dissipating phase; the electrostatic phenomena ensure the balance.

b) Dry silica dust - concentrated; character: as above with the difference that part of the disperse phase was removed by venting and pressing.

c) Aqueous suspension of silica (with or without additives) - similar to a solid phase colloidal suspension of silica particles and microparticles and a dispersion phase - water with optionally dissolved additives.

There are also other forms of microsilica that are not used in construction: silica granules, silica sludge and agglomerated silica dust [9].

Silica may be white or dark and when mixed with water gives a suspension that is black. The color of silica dust depends on the carbon content, the higher content, so the darker the color of the material [26]. The specific surface area of silica dust is usually measured by the method $\mathrm{BET}^{1}$ and is within the limits of 13000 do $20000 \mathrm{~m}^{2} / \mathrm{kg}$; average grain sizes are on the level

\footnotetext{
The Brunauer-Emmett-Teller multi-layer adsorption isotherm (BET) describes a model in which a hypothetical but countable monomolecular layer of adsorbed gas is distinguished [27].
} 
Table 3. Chemical composition of silica fumes from silicon ovens in Norway, North America and Poland [9, 25].

\begin{tabular}{|c|c|c|c|}
\hline $\begin{array}{c}\text { Constituent, } \\
{[\%]}\end{array}$ & Norway ${ }^{1)}$ & $\begin{array}{c}\text { North } \\
\text { America }^{2}\end{array}$ & Poland $^{3)}$ \\
\hline $\mathrm{SiO}_{2}$ & $90.0-96.0$ & 93.7 & $86.93-97.60$ \\
\hline $\mathrm{Al}_{2} \mathrm{O}_{3}$ & $0.5-3.0$ & 0.3 & $0.55-3.61$ \\
\hline $\mathrm{Fe}_{2} \mathrm{O}_{3}$ & $0.2-0.8$ & 0.8 & $0.17-2.03$ \\
\hline $\mathrm{MgO}$ & $0.5-1.5$ & 0.2 & $0.02-1.22$ \\
\hline $\mathrm{CaO}$ & $0.1-0.5$ & 0.2 & Traces -0.89 \\
\hline $\mathrm{Na}_{2} \mathrm{O}$ & $0.2-0.7$ & 0.2 & $0.11-0.37$ \\
\hline $\mathrm{K}_{2} \mathrm{O}$ & $0.4-1.0$ & 0.5 & $0.31-1.49$ \\
\hline
\end{tabular}

${ }^{1)}$ From brochure Elkem Silica, Elkem - Spigerverket A/S,

Norway

${ }^{2}$ From a plant in Eastern Canada

${ }^{3)}$ Eaziska steelworks.

0,02-0,45 $\mu \mathrm{m}$, (on average, cement grains are 100 times larger) [26, 28]. The density of typical silica dust is low at about $2.2 \mathrm{~g} / \mathrm{cm}^{3}$; for comparison, the density of Portland cement is about $3.1 \mathrm{~g} / \mathrm{cm}^{3}$. Unconcentrated dust unit mass is from 250 to $300 \mathrm{~kg} / \mathrm{m}^{3}$, while for cement this value is about $1200 \mathrm{~kg} / \mathrm{m}^{3}$ [9].

Silica dust was classified by The American Concrete Institute (ACI) as part of such cementitious materials as pozzolan [29]. ASTM C $618^{2}$ recognizes three classes of pozzolan: $\mathrm{N}, \mathrm{F}$ and $\mathrm{C}$.

- Class N: Raw or calcined natural pozzolans that comply with the applicable requirements for the class as given herein, such as some diatomaceous earths; opaline cherts and shales; tuffs and volcanic ashes or pumicites, calcined or uncalcined; and various materials requiring calcination to induce satisfactory properties, such as some clays and shales.

- Class F: Fly ash normally produced from burning anthracite or bituminous coal that meets the applicable requirements for this class as given herein; this class of fly ash has pozzolanic properties.

- Class C: Fly ash normally produced from lignite or subbituminous coal that meets the applicable requirements for this class as given herein; this class of fly ash, in addition to having pozzolanic properties, also has some cementitious properties [30].

Silica dust is the closest to the $\mathrm{N}$ class. However, there are no detailed guidelines to allow unambiguous inclusion of silica dust in a given class [31].

\section{Research of Concretes with Silica}

Even small amounts of silica dust added to concrete mix improve its properties compared to concrete without additives [10, 32] (Fig. 2).

\footnotetext{
Standard Specification for Coal Fly Ash and Raw or Calcined Natural Pozzolan for Use in Concrete [30].
}

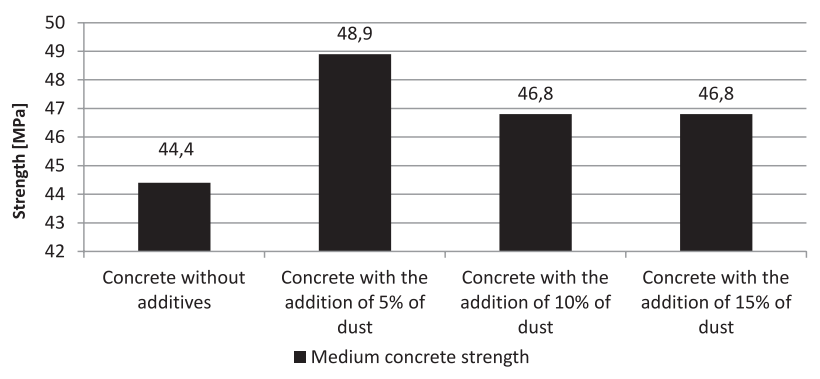

Fig. 2. Average of compressive strength concrete after 28 days (based on [10]).

The introduction of silica dust changes the physical properties of the fresh concrete mix, which has a significant impact on the way it is laid and compacted. With a low content of silica dust (less than $3 \%$ of the binder mass), liquefaction of the concrete mix is sometimes observed. It is connected with the fact that very small dust particles occupy the place of water displacing its apparent excess from between the cement grains. However, in general, the introduction of microsilica is accompanied by a completely opposite effect - the very large developed surface of the additive is the reason that it adsorbs water and the concrete mix with its content is faster gelling and it cannot be used without liquefying agents. Very small particles of this additive affect the cohesiveness and decrease the plasticity of the concrete mix, which results in increased water demand, but on the other hand it prevents the segregation of ingredients, especially the release of water $[9,33]$.

The addition of silica dust in the cement increases the density of the material (high $\mathrm{SiO}_{2}$ content) and enhances the pozzolanic action in the concrete. However, significant dust fragmentation hinders the physical use of silica dust, among others, hindering the workability of the mixture. This was confirmed by the studies carried out using Portland cement containing from 10 to $30 \%$ of weight silica dust. It was found that the plasticity of mortars decreases with the increase in the amount of dust. Their addition of $10 \%$ results in a reduction of the plasticity by about $10 \%$ compared to the control mortar without addition. With the addition of $20 \%$, the plasticity of the mortar is reduced by approximately $30 \%$, while $30 \%$ of the dust reduces the plasticity by nearly $40 \%$ [9]. When using silica dust in concrete to improve the dispersion of this additive, plasticizers or superplasticizers are used [33-35].

According to the results of some studies, silica dust added to concrete has an impact on improving its mechanical properties and increasing resistance to freezing and thawing, vibration damping, tightness, abrasion resistance, corrosion of steel reinforcing bars and binder strength with steel reinforcing bars. Silica dust as an additive to concrete also reduces its alkalisilica reactivity, creep and shrinkage of concrete, permeability and thermal expansion [5, 22, 36-37]. Due 
to the increased resistance to abrasion of concrete with the addition of silica dust in relation to concrete without this additive, it is used in the construction of runways, structural elements of bridges and viaducts, as well as the surface of roads, bridges and parking lots. One of the most important features that concrete acquires thanks to silica dust is its resistance to the destructive effect of de-icing salts [38-39]. Typical concrete mixes contain added dust in the amount of $7.5-10 \%$, which clearly improves the usable durability of the concrete, preventing its destruction. Silica dust affects the structure of the pores by reducing the capillary pores

Table 4. Occupational guidance values for quartz/crystalline silica [71].

\begin{tabular}{|c|c|c|c|c|c|}
\hline Organization* & Chemical(s) & Name & Year & Guidance Value & Target Population \\
\hline $\begin{array}{l}\text { Mine Safety and Health } \\
\text { Administration (MSHA) }\end{array}$ & $\begin{array}{l}\text { Crystalline } \\
\text { Silica, quartz }\end{array}$ & $\begin{array}{l}\text { Permissible exposure limit } \\
\text { (PEL) }\end{array}$ & 2001 & $\begin{array}{l}10 \mathrm{mg} / \mathrm{m}^{3}\left(\% \mathrm{SiO}_{2}+2\right) \\
\text { (respirable dust contain- } \\
\text { ing crystalline silica) } \\
10 \mathrm{mg} / \mathrm{m}^{3} \text { (total dust) }\end{array}$ & Miners \\
\hline $\begin{array}{c}\text { Occupational Safety and } \\
\text { Health Administration } \\
\text { (OSHA) }\end{array}$ & $\begin{array}{l}\text { Silica, } \\
\text { Crystalline } \\
\text { Quartz }\end{array}$ & PEL - current & 1978 & $\begin{array}{c}250 \mathrm{mppcf} * * \% \mathrm{SiO}_{2}+5 \\
\text { (TWA, respirable dust) } \\
10 \mathrm{mg} / \mathrm{m}^{3} \% \mathrm{SiO}_{2}+2 \\
\text { (TWA, respirable dust) } \\
30 \mathrm{mg} / \mathrm{m}^{3} \% \mathrm{SiO}_{2}+2 \\
\text { (TWA, total dust) }\end{array}$ & $\begin{array}{l}\text { General Industry } \\
\text { (also same for } \\
\text { construction and } \\
\text { shipyard employ- } \\
\text { ment) }\end{array}$ \\
\hline $\begin{array}{c}\text { Occupational Safety and } \\
\text { Health Administration } \\
\text { (OSHA) }\end{array}$ & $\begin{array}{c}\text { Silica, } \\
\text { Crystalline } \\
\text { Quartz } \\
\end{array}$ & PEL - proposed & 2014 & $\begin{array}{c}50 \mu \mathrm{g} / \mathrm{m}^{3} \\
\text { (TWA, respirable) }\end{array}$ & $\begin{array}{l}\text { General industry/ } \\
\text { maritime; con- } \\
\text { struction } \\
\end{array}$ \\
\hline $\begin{array}{l}\text { National Institute for } \\
\text { Occupational Safety and } \\
\text { Health (NIOSH) }\end{array}$ & $\begin{array}{l}\text { Crystalline } \\
\text { Silica }\end{array}$ & $\begin{array}{l}\text { Recommended Exposure } \\
\text { Limit (REL) }\end{array}$ & $\begin{array}{c}1974, \\
2002 \\
\text { (update) }\end{array}$ & $\begin{array}{c}0.05 \mathrm{mg} / \mathrm{m}^{3} \text { (TWA, respi- } \\
\text { rable dust) } \\
\text { Cancer }-\mathrm{Ca}\end{array}$ & General workers \\
\hline $\begin{array}{c}\text { American Conference of } \\
\text { Governmental Industrial } \\
\text { Hygienists (ACGIH) }\end{array}$ & $\begin{array}{c}\text { Silica, } \\
\text { Crystalline } \\
\text { Quartz } \\
\end{array}$ & $\begin{array}{l}\text { Threshold Limit value } \\
\text { (TLV) }\end{array}$ & 2010 & $\begin{array}{c}0.025 \mathrm{mg} / \mathrm{m}^{3} \text { (respirable } \\
\text { aerosol fraction) } \\
\text { Cancer }-\mathrm{A} 2\end{array}$ & General workers \\
\hline California OSHA & $\begin{array}{l}\text { Silica crystal- } \\
\text { line, quartz }\end{array}$ & PEL & 2008 & $\begin{array}{l}0.1 \mathrm{mg} / \mathrm{m}^{3} \text { (TWA, respi- } \\
\text { rable dust) } \\
0.3 \mathrm{mg} / \mathrm{m}^{3} \text { (TWA, total } \\
\text { dust) }\end{array}$ & General workers \\
\hline $\begin{array}{l}\text { Scientific Committee on } \\
\text { Occupational Exposure } \\
\text { Limits (SCOEL) }\end{array}$ & $\begin{array}{l}\text { Silica crysta- } \\
\text { line (Quartz) }\end{array}$ & $\begin{array}{l}\text { Occupational Exposure } \\
\text { Limit (OEL) }\end{array}$ & 2003 & $\begin{array}{c}<0.05 \mathrm{mg} / \mathrm{m}^{3} \\
\text { (respirable dust) }\end{array}$ & General workers \\
\hline $\begin{array}{c}\text { Germany } \\
\text { Deutsche Forschungsge- } \\
\text { meinschaft } \\
\text { (DFG) }\end{array}$ & $\begin{array}{l}\text { Crystalline } \\
\text { quartz }\end{array}$ & $\begin{array}{l}\text { Maximale arbeitsplatz- } \\
\text { konzentration (MAK): } \\
\text { maximum workplace } \\
\text { concentration }\end{array}$ & 2000 & Cancer Notation: 1 & General workers \\
\hline Safe Work Australia & $\begin{array}{l}\text { Crystalline } \\
\text { quartz }\end{array}$ & $\begin{array}{c}\text { National Exposure } \\
\text { Standard }\end{array}$ & 2005 & $0.1 \mathrm{mg} / \mathrm{m}^{3}$ & General workers \\
\hline Canada - Ontario & Silica, fused & & & $\begin{array}{c}0.1 \mathrm{mg} / \mathrm{m}^{3} \\
\text { (respirable dust) }\end{array}$ & \\
\hline New Zealand & Silica, fused & & & $\begin{array}{c}0.2 \mathrm{mg} / \mathrm{m}^{3} \\
\text { (respirable dust) }\end{array}$ & \\
\hline Switzerland & $\begin{array}{l}\text { Silica, fused, } \\
\text { respirable dust }\end{array}$ & & & $\begin{array}{c}0.3 \mathrm{mg} / \mathrm{m}^{3} \\
\text { (respirable aerosol) }\end{array}$ & \\
\hline
\end{tabular}

TWA $-8 \mathrm{~h}, 40 \mathrm{~h}$ week weighted average concentration, which cannot be exceeded during an 8-hour work shift and 40-hour work week.

* Many individual countries (not listed here) also have published occupational exposure limits for silica, but they are duplicates of the values already listed in the table.

** Millions of particles per cubic foot of air (mppcf), based on impinger samples counted by light-field techniques. Conversion factors $-10 \mathrm{mppcf}=0.1 \mathrm{mg} / \mathrm{m}^{3} ;$ mppcf $\times 35.3=$ million particles per cubic meter $=$ particles per c.c. 
and by creating new structures of hydrated calcium silicates type C-S-H. This results in increased density of the cement stone matrix, manifesting itself, for example, in the reduction of water permeability of concrete as well as concrete permeability for other liquids and gases, which increase concrete resistance to corrosive agents $[9,40]$.

Many laboratory tests were carried out on concrete used for years in various environments. Finally, it was found that the test methods are effective in assessing the relative quality of the material and are not intended to measure the expected life of a particular surface. There is not one abrasion test that fits perfectly on all surfaces, but you can distinguish some that are more suitable for specific applications. Most testing methods, as described in the literature, use the technique of measuring wear depth at various exposure times as direct measures of abrasion resistant surface. There is also the technique of weighing samples at regular intervals [5, 39, 41].

ASTM short-term abrasion tests were normalized, including: sanding (ASTM C 418), rotary knife (ASTM C 994), revolving-disk machine (ASTM C 779, procedure A), dressing-wheel machine (ASTM C 779, procedure B) and ball bearing machine (ASTM C 779, procedure $\mathrm{C}$ ). However, there is little available published data on the tests of concrete with silica wear, and almost all of the tests described have been based on silica dust technology replacing part of Portland cement [5].

Some of the more interesting results are described in the work of Linch [42]. It was found that during drilling in concrete road pavement concentrations of quartz particles in the air were in the range of $4,4 \mathrm{mg} / \mathrm{m} 3$ for a 358-minute sample, which gives an eight-hour weighted average of $3,3 \mathrm{mg} / \mathrm{m}^{3}$. However, during the milling of asphalt samples taken from concrete surface, there was a quartz concentration in the range of up to $0,34 \mathrm{mg} / \mathrm{m}^{3}$ for a 504-minute sample, and as a result of an eight-hour weighted average was $0,36 \mathrm{mg} / \mathrm{m}^{3}$ [42]. It draws attention to the fact that global amounts of silica are likely to be released into the air during the wear of concrete surfaces with the addition of silica dust. However, so far no probable amounts have been estimated or measured that may be subject to these releases.

\section{Effect of Silica Dust on Human Health}

There is epidemiological and toxicological evidence for a clear relationship between the number (PNC) or mass concentration (PMC) of particulate matter (PM), in particular their ultrafine fraction $(<100 \mu \mathrm{m})$ and human health [43-44]. It is very important for particle size that the finer the particles, the deeper they enter the respiratory system, increasing the risk of lung and cardiovascular diseases [45]. There are many PM particle sources in the urban environment. For the smallest particles (nano- and ultrafine particles), their number in the air volume (PNC) is usually determined, whereas for the PM10, PM2.5 or PM1 fraction (i.e., with the aerodynamic diameter $\leq 10, \leq 2.5, \leq 1 \mu \mathrm{m}$ respectively) mass concentrations (PMC) are determined [46]. Emissions from vehicle engines are defined as a significant source of the finest particles [47-48], while road dust associated with abrasion of car body elements and resuspension of street dust/soil is the main source of thicker particles [49-50].

Many construction activities related to the creation and management of urban infrastructure are also the source of particles, especially those which belong to the PM10 fraction [51-52]. For example, Fuller and Green [53] showed that emission of PM10 during road works gives a trigger to concentrations exceeding the value established in the European Union as an acceptable daily concentration of PM10 $\left(50 \mu \mathrm{g} / \mathrm{m}^{3}\right)$. There are also scientific reports suggesting that abrasion of road surfaces is the source of ultrafine particles $[48,54-$ 55]. There is significantly less research devoted to concentrations and particle size distributions during the production, processing and use of various types of technical materials $[44,56]$. There are several studies on PM emissions from drilling and cutting materials such as carbon nanofibers [57], as well as composite and silicon nanocomposites [58], construction demolitions [59-60], concrete recycling [46] and other construction and road works $[53,61]$. The significance of particulate emissions from building sources is likely to increase as it is expected that the development of urban infrastructure around the world will reflect the increase in the world's population [62].

In general, it can be briefly summarized that many PM studies were carried out in urban areas, but few of them focused on PM in construction works [34, 63], or PM from road surfaces abrasion [64]; the minimum amount of data in this range can be found for the smallest PM particles below $100 \mu \mathrm{m}$ [48].

Currently, there are no legal provisions or guidelines for controlling human exposure to ultrafine particles in the urban environment, including their impact on construction sites or areas adjoining busy roads [46, 6566]. Meanwhile, construction activities, such as mixing, drilling and cutting concrete, as well as concrete abrasion (e.g., of concrete road surface by moving vehicles) have the potential to generate PM particles from any size range [67-68].

It was proved that professional exposure to dust containing crystalline silica occurs in mining industries, metal foundries, construction, manufacture of glass, ceramics, concrete and granite and stonework industries [69]. Production of concrete products such as brick, tile and sewer drains, as well as some materials for the production or repair of road surfaces, require the use of silica, sand and cement. Quartz, tridymite and cristobalite are the three important crystalline forms of crystalline silica, for which the values of permissible concentrations in the working environment were determined [70-72].

A thorough search was conducted to identify all existing occupational exposure guidance values applicable to crystalline silica/quartz. These values are 


\begin{tabular}{|c|c|c|c|c|c|c|}
\hline 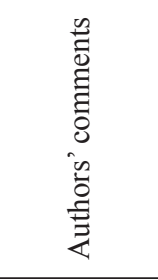 & & & 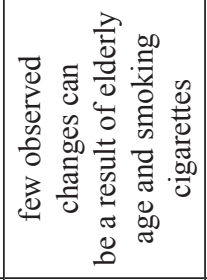 & 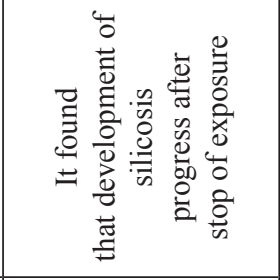 & & 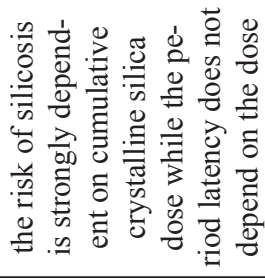 \\
\hline 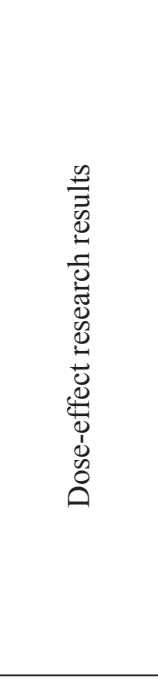 & & 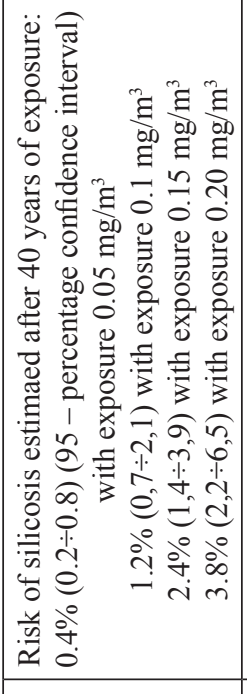 & 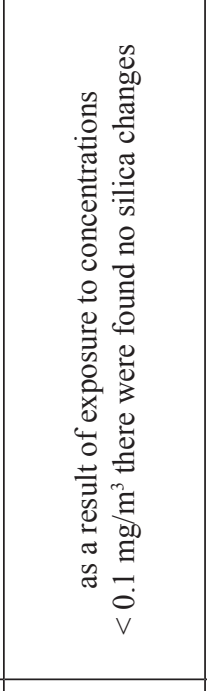 & 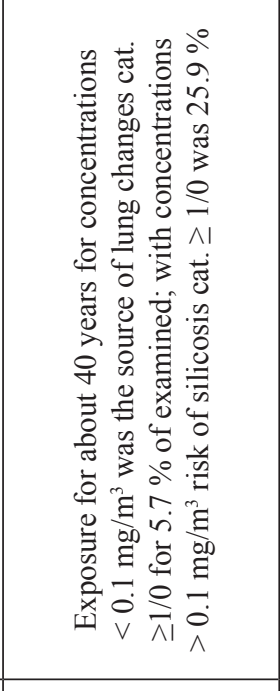 & 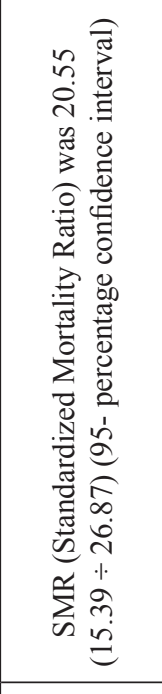 & 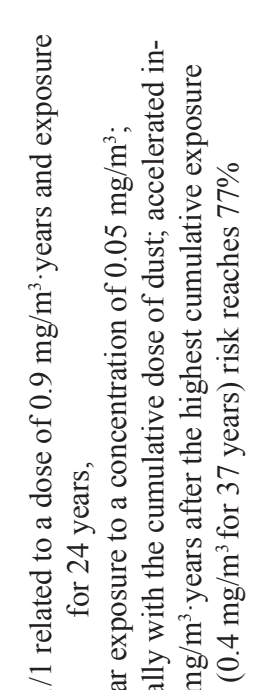 \\
\hline 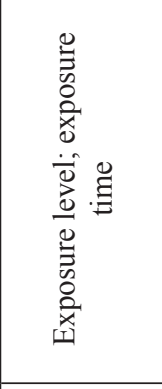 & $\begin{array}{l}0 \\
0 \\
0 \\
0 \\
0 \\
0 \\
0 \\
0 \\
0 \\
0 \\
0 \\
0 \\
0 \\
0 \\
0 \\
.00 \\
.0 \\
0 \\
0 \\
0 \\
0\end{array}$ & 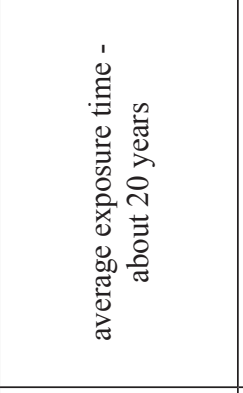 & 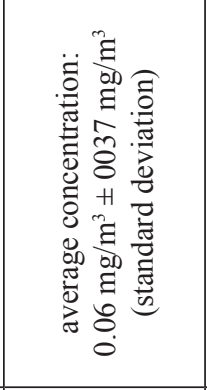 & 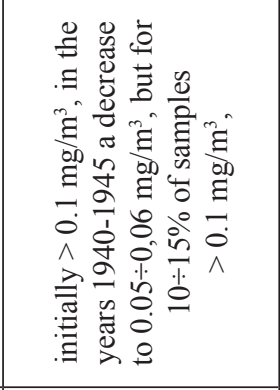 & 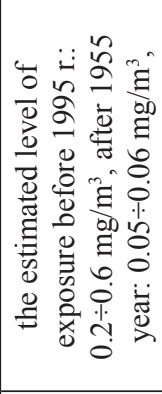 & 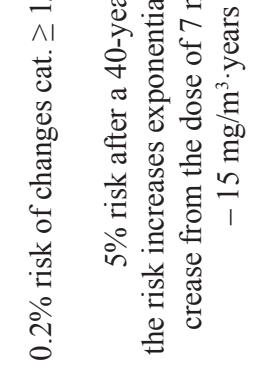 \\
\hline 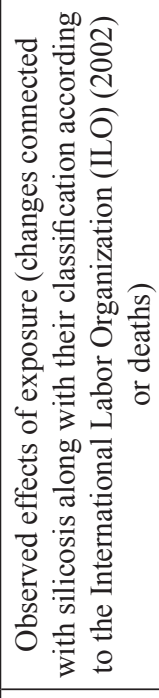 & 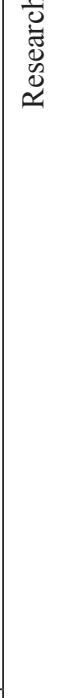 & 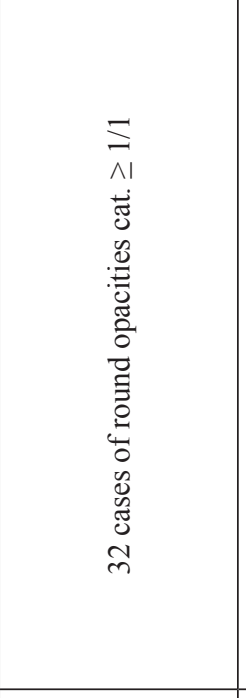 & 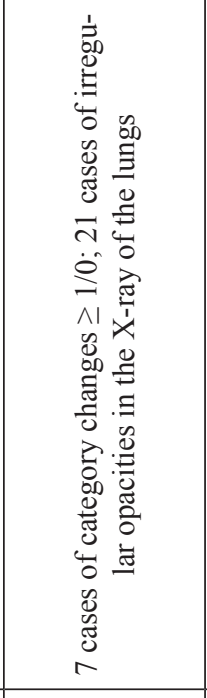 & 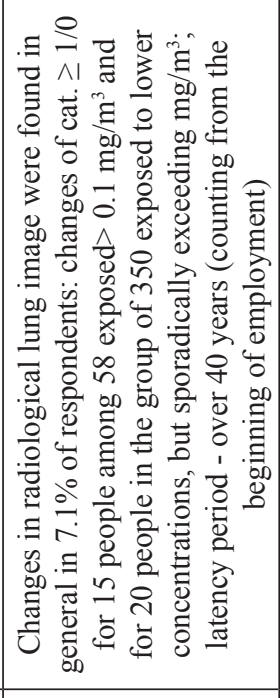 & & 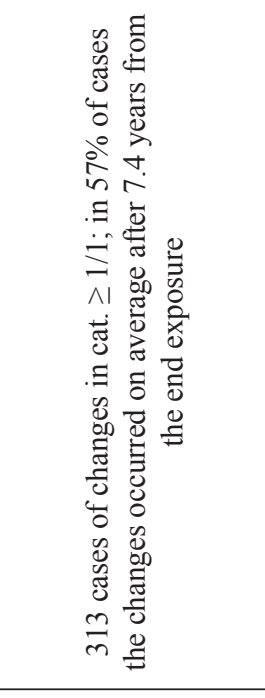 \\
\hline 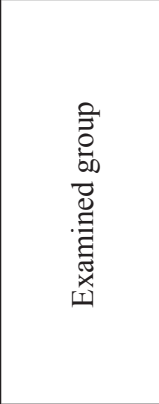 & & 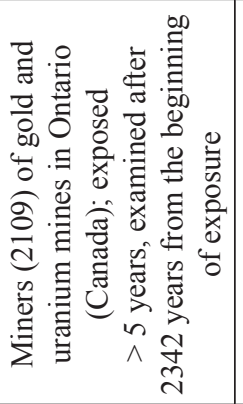 & 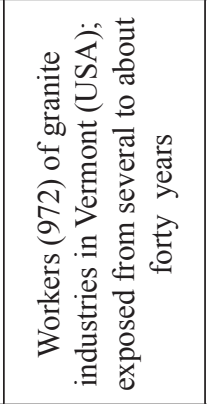 & 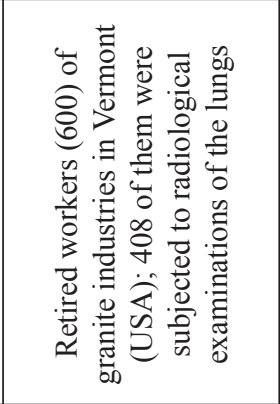 & 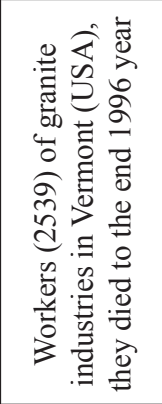 & 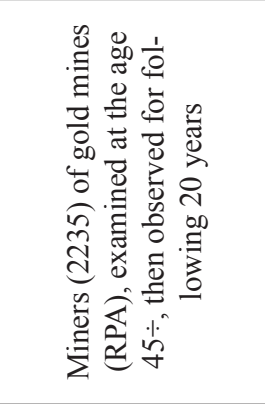 \\
\hline
\end{tabular}




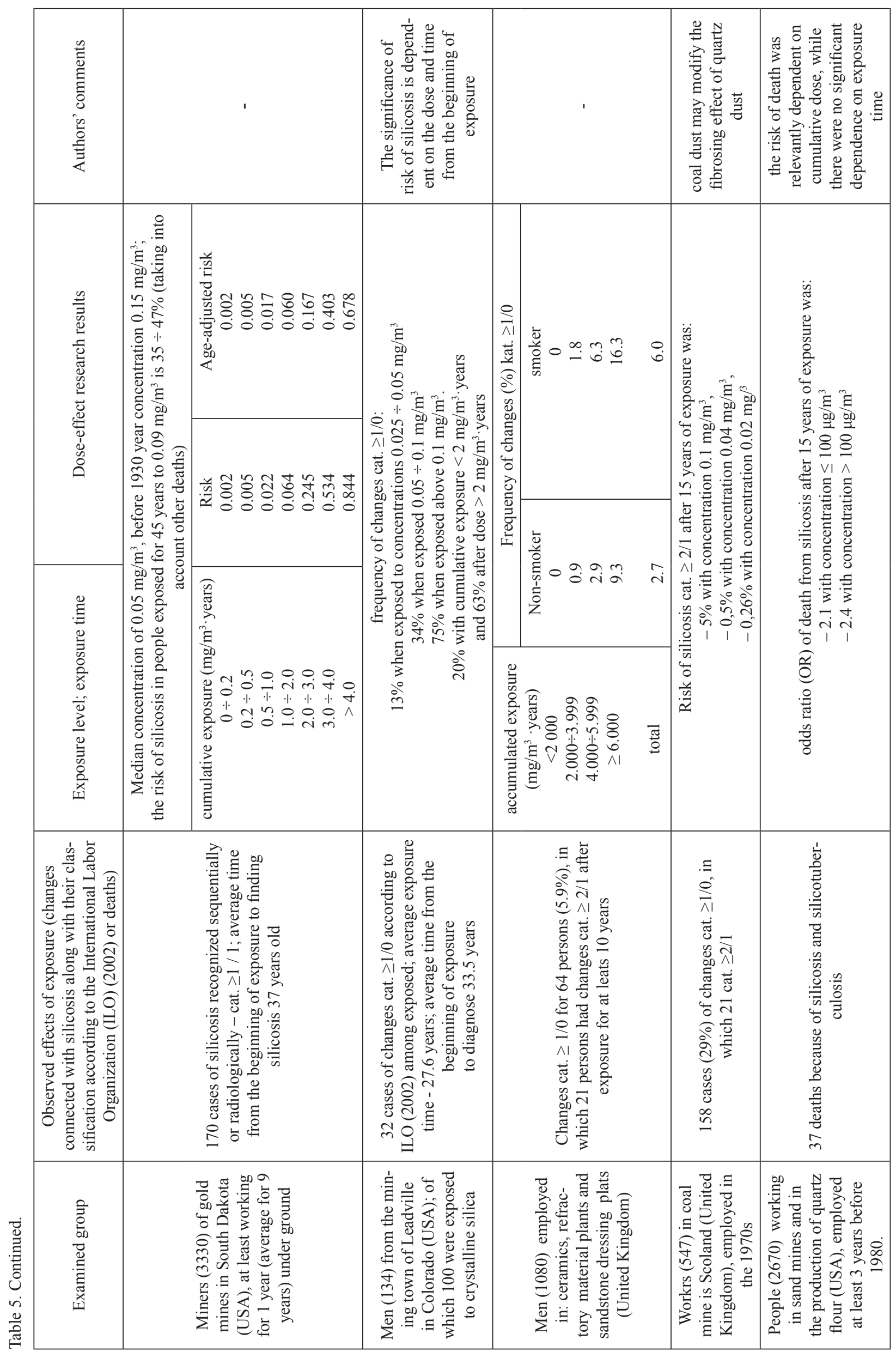




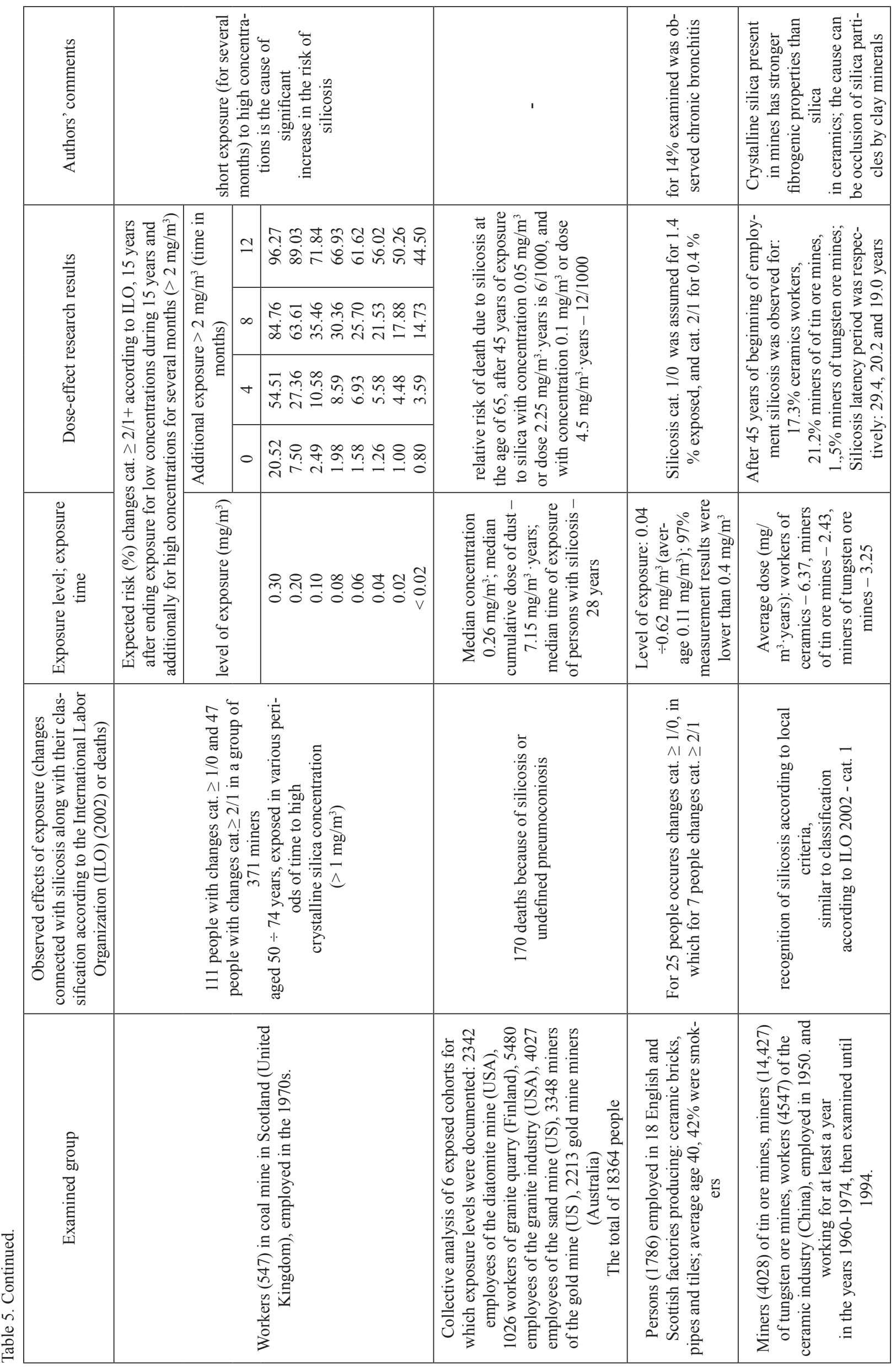




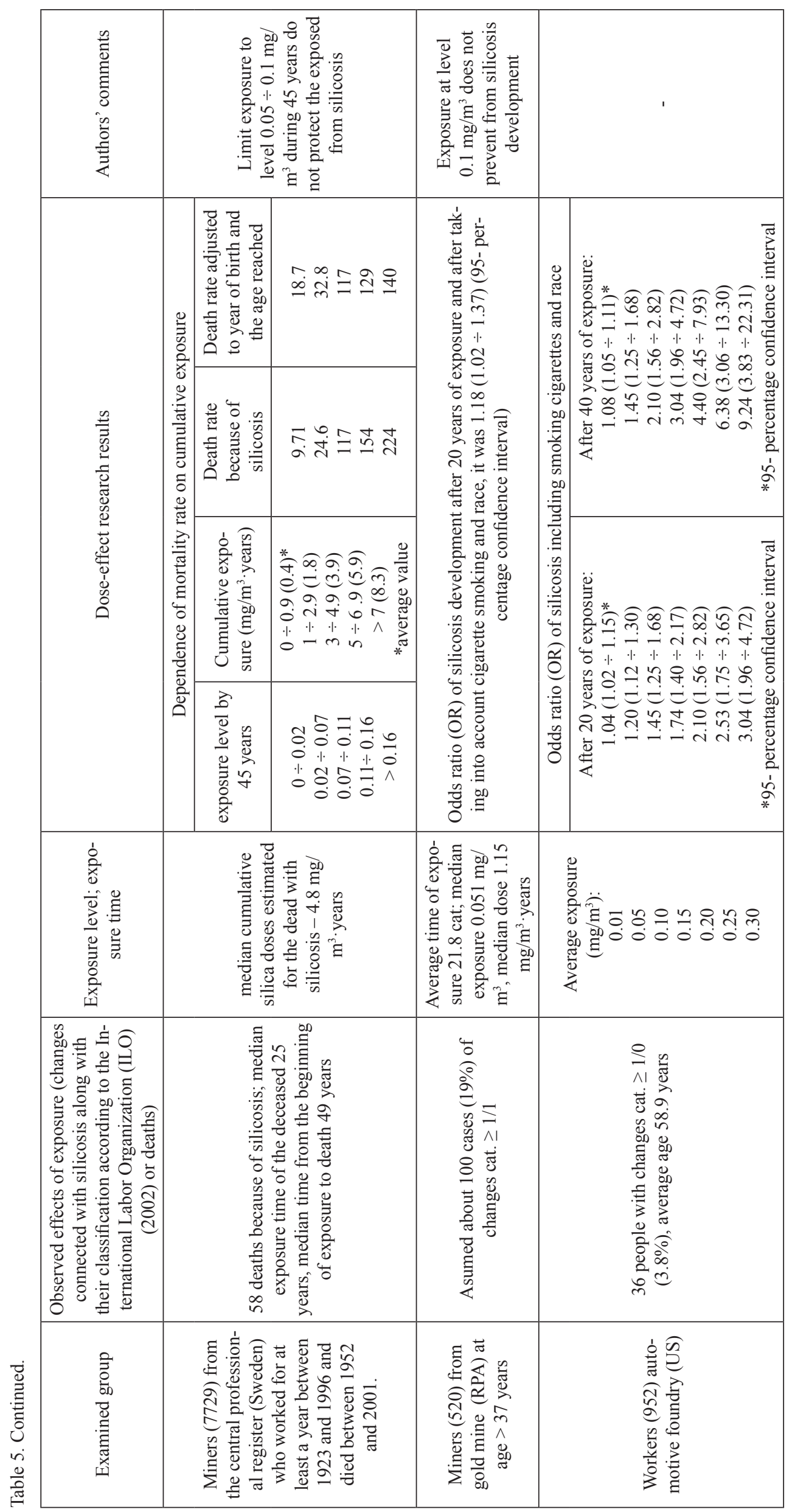




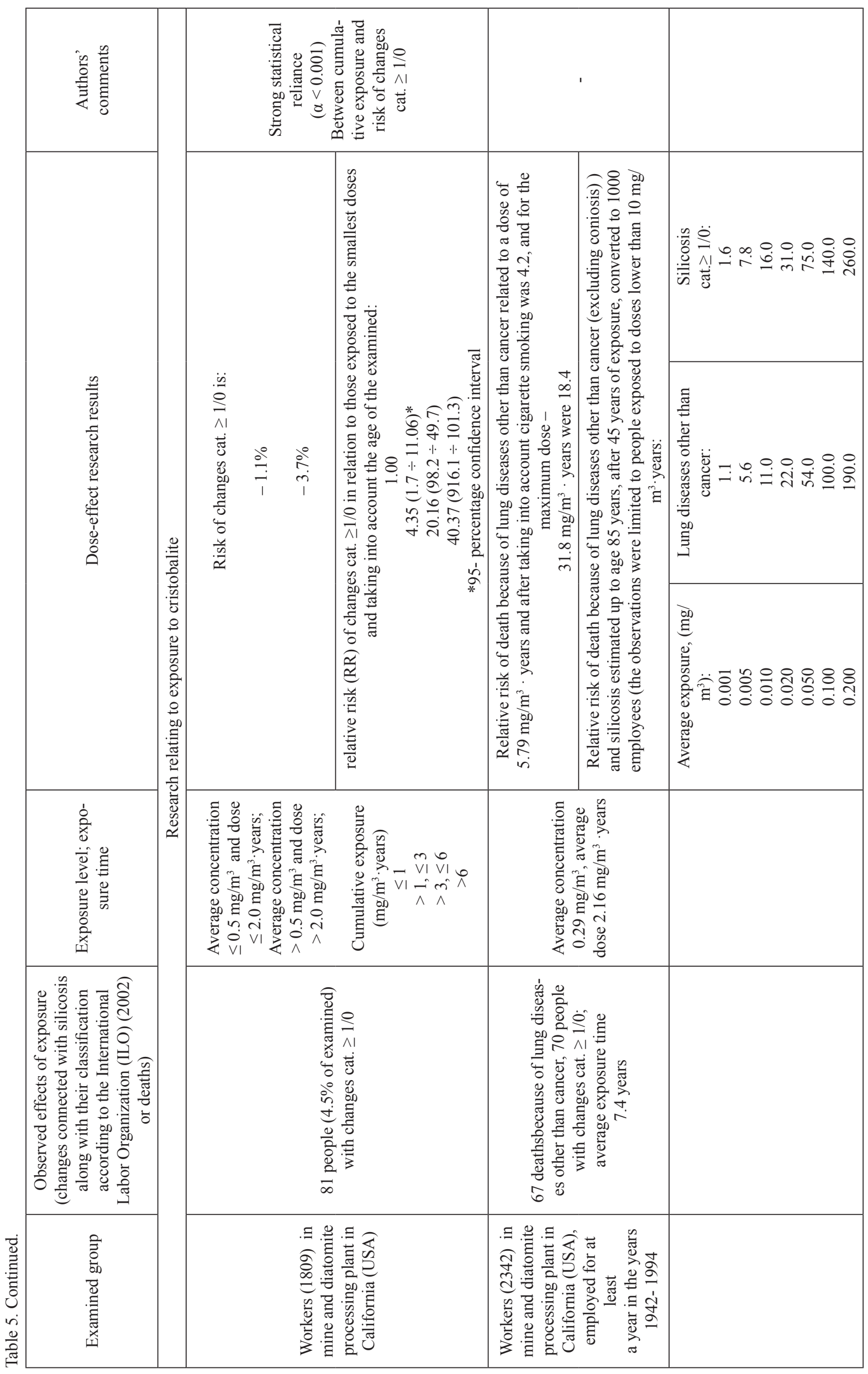


listed in Table 4 and include the year of assessment, chemical type, guidance value, target population, and the source of this information.

Diseases caused by the inhalation of free crystalline silica are silicosis, pulmonary tuberculosis, lung cancer, chronic obstructive pulmonary disease (COPD) and several extra pulmonary diseases [70, 73]. It is assumed that pulmonary silicosis requires exposure to high levels of dust for a long time. Many studies describe the quantitative relationship between silica exposure and pneumonia, emphysema, and obstruction as aspects of silicosis [66, 74-75]. There was also evaluated a correlation between cumulative dust exposure and an increased risk of deaths due to COPD in combination with smoking [76]. In South African studies, chronic bronchitis associated with loss of lung function was found among gold miners. These results were strongly related to exposure to dust containing silica and not depending on silicosis [74].

Exposure to crystalline silica can cause both respiratory and non-respiratory effects. It was found that silicosis among the diseases of the respiratory system is one of the best-documented occupational diseases [77]. Every year, about 100 workers in the U.S. die from silicosis, while hundreds of people suffer from breathing difficulties such as bronchitis. Over 2 milion U.S. workers are exposed to high risks associated with silica as a result of construction and mining activities $[75,78]$. There is a connection between exposure to crystalline silica and other health problems, including rheumatoid arthritis, scleroderma, Sjogren's syndrome, lupus and kidney disease [71]. NIOSH believes that more attention should be paid to these atypical health effects [76].

Based on epidemiological studies, crystalline silica dust was classified as a known carcinogen for humans [70, 79-80]. The study of mortality among industrial workers confirmed the causal link between lung cancer and crystalline silica exposure [75, 81-82].

It can be concluded that exposure to silica is clearly greater for people working in the construction industry than for other professions. Exposure to silica at a construction site is much more common than in any other industry, so there is increased mortality due to silicosis among construction workers, as well as increased risk associated with lung cancer through contact with silica. It was reported that people exposed to concrete containing silica dust suffer from reduced lung function $[75,83]$.

Although workers exposed to silica are at the same time exposed to a mix of other pollutants, including nitrogen gases and diesel exhaust emissions, research suggests that lung diseases can be largely caused by the inhalation of silica dust [84]. Epidemiological studies on occupational exposure to crystalline silica are carried out for decades; the list of selected ones are prepared in Table 5 [70].

\section{Conclusions}

Many organizations have focused recently on environmental protection research in the construction industry. One of the pro-ecological activities is using less energy-consuming cement materials such as fly ash, slag and pozzolan. It was also pointed out that condensed silica has the possibility of wide use as a partial substitute for cement (concrete additive). Currently, high-quality concrete for road and highway construction is increasingly used, and it is also used for road renovation/repair. It seems that all this causes silica, in a much larger quantity than is generally estimated, to be introduced into the environment, especially to the atmosphere and the ground environment. The problem of excessive inhalation of silica may be important due to health exposure, not only in groups of people professionally exposed to its inhalation such as construction industry workers and miners, but also commonly in humans and everywhere where there is a lot of silica in the atmosphere. So far, the problem of silica pollution was important only from the point of view of the working environment, so it was associated with occupational exposure. In the case of environmental research, silicon or silica in the samples are treated as indicators of the impact of natural sources in a given area, and therefore their occurrence is associated with the composition of soils or upper continental crust $[88,89]$.

Efforts have been made to collect and summarize information on exposure to silicon dust in the mining and construction industries [70, 75, 82, 85-87]. However, the exposure levels during specific construction work - or the indication of silica concentrations in the air during such work - are insufficiently characterized. This particularly applies to work related to the performance and repair of concrete road surfaces, which, as shown in this paper, are probably related to the increase in the concentration of silica in the air. Sampling of silica dust under its natural emission conditions (e.g., road surface abrasion) may create many problems due to dynamically changing environmental conditions as well as many sources of dust in urban areas. Another problem in this area is the use of specific and sensitive analytical methods for determining small amounts of silica in environmental samples. Therefore, the attempt to determine the emission trigger of road surface abrasion to the total balance of crystalline silica in the air seems to be an essential element of research that should be developed in coming years.

\section{Conflict of Interest}

The authors declare no conflict of interest. 


\section{References}

1. DOBISZEWSKA M., FRANUS W., TURBIAK S. Analysis of the possibility of using powder basalt in cement mortar. J. Civ. Eng. Environ. Archit. 63, 107-114, 2016.

2. SARAYA M.E.I. Study physico-chemical properties of blended cements containing fixe amount of silica fume, blast furnace slag, basalt and limestone, a comparative study. Constr. Build. Mater. 72, 104, 2014.

3. SIDDIQUE R. Utilization of silica fume in concrete: Review of hardened properties. Resour. Conserv. Recy. 55 (11), 923, 2011.

4. SIDDIQUE R., CHAHAL N. Use of silicon and ferrosilicon industry by-products (silica fume) in cement paste and mortar. Resour. Conserv. Recy. 55 (8), 739, 2011.

5. GHAFOORI N., DIAWARA H. Abrasion Resistance of Fine Aggregate - Replaced Silica Fume Concrete. Materials 96 (5), 559, 1999.

6. RASHAD A.M., SELEEM H.E.D.H., SHAHEEN A.F. Effect of Silica Fume and Slag on Compressive Strength and Abrasion Resistance of HVFA Concrete. Int. J. Concr. Struct. M. 8 (1), 69, 2014.

7. WANG F., ZHENG S.S., WANG X.F. Influence of Silica Fume on High-Performance Concrete. Appl. Mech. Mater. 670-671, 437, 2014.

8. AMUDHAVALLI N.K., MATHEW J. Effect of Silica Fume on Strength and Durability Parameters of Concrete. Int. J. Eng. Sci. Tech. 3 (1), 28, 2012.

9. JASICZAK J., MIKOŁAJCZAK P. Technologia betonu modyfikowanego domieszkami i dodatkami. Alma Mater 2003 [In Polish].

10. RUTKOWSKA G., SOBCZAK M. Concrete Modified With Silica Dust. Acta Sci. Pol., Technica Agraria 13 (1-2), 3, 2014.

11. PN-EN 13263-1:2010 (U). Część 1: Definicje, wymagania i kryteria zgodności [In Polish].

12. PN-EN 206:2014 Beton. Część 1: Wymagania, właściwości, produkcja i zgodność [In Polish].

13. GIERGICZNY Z., BATOG M., DZIUK D., GOLDA A., GRABSKI J., KASZUBA S., SOKOŁOWSKI M., SYNOWIEC K., SZUBA J., WĄSIK M. Cement, kruszywa, beton w ofercie Grupy Górażdże - Rodzaje, właściwości, zastosowanie. HEIDELBERGCEMENT Group. 2016 [In Polish].

14. SHOUKRY H. SHEBL S.S., KHALIL I.S. Preparation of ultra-fine silica particles and their application for enhanced strength of cement mortar. Cem. Wapno Beton 1, 17, 2014.

15. NEVILLE A.M. Properties of Concrete. Prentice-Hall Publications, New Jersey, 2011.

16. KHAN M.I., SIDDIQUE R. Utilization of silica fume in concrite: Review of durability properties. Resour. Conserv. Recy. 57, 30, 2011.

17. CHAPLIN R.G. The Abrasion Resistance of Concrete Floors. Technical Report 42.471. Cement and Concrete Association, London, 1, 1972.

18. HUNCHATE S.R., CHANDUPALLE S., GHORPODE V.G., REDDY V. Mix Design of High Performance Concrete Using Silica Fume and Superplasticizer. Int. J. Innov. Res. Sci. Eng. Technol. 3 (3), 10735, 2014.

19. KHAN M.I. Nanosilica/silica fume. Waste and Supplementary Cementitious Materials in Concrete. Characterisation, Properties and Applications. Woodhead Publishing Series in Civil and Structural Engineering. 461, 2018.
20. EL-DIDAMONY H., HEIKAL M., AIAD I., AL-MASRY S. Behavior of Delayed Addition Time of SNF Superplasticizer on Microsilica-Sulphate Resisting Cements. Ceramics - Silikáty 57 (3), 232, 2013.

21. GRZESZCZYK S. Betony nowej generacji z proszków reaktywnych. Biuletyn Wojskowej Akademii Technicznej. 64 (3), 103, 2015 [In Polish].

22. SHARMA U., KHATRI A., KANOUNGO A. Use of Micro-silica as Additive to Concrete-state of Art. Int. J. Civ. Eng. Res. 5 (1), 9, 2014.

23. SILITONGA E. Experimental Research of Stabilization of Polluted Marine Dredged Sediments By Using Silica Fume. Matec Web of Conferences, EACEF, Sustainable Construction Material 138, 10, 2017.

24. TAKLA M., KAMFJORD N.E., TVEIT H., KJELSTRUP S. Energy and exergy analysis of the silicon production process. Energy 58, 138, 2013.

25. MALHOTRA V.M., CARETTE G.G. Silica Fume Concrete - Properties, Applications, and Limitations. Concrete International 40, 1983.

26. MAJCHROWICZ I., BARAŃSKI J. The relationship between the properties of low-cement high-alumina castable and microsilica content in the matrix. Scientific Works of Institute of Ceramics and Building Materials 12, $51,2013$.

27. BRUNAUER S., EMMETT P.H., TELLER Z. Adsorption of Gases in Multimolecular Layers. 1938.

28. HANUMESH B.M., VARUN B.K., HARISH B.A. The Mechanical Properties of Concrete Incorporating Silica Fume as Partial Replacement of Cement. Int. J. Emer. Technol. Adv. Eng. 5 (9), 270, 2015.

29. ACI Committee 226. Silica fume in concrete. ACI Mat. J. 84, 158, 1987.

30. ASTM International C 618. Standard Specification for Coal Fly Ash and Raw or Calcined Natural Pozzolan for Use in Concrete.

31. SENHADJI Y., ESCADEILLAS G., MOULI M., KHELAFI H., BENOSMAN. Influence of natural pozzolan, silica fume and limestone fine on strength, acid resistance and microstructure of monar. Powder Technol. 254, 314, 2014.

32. MONDAL P., SHAH S.P., MARKS L.D., GAITERO J.J. Comparative Study of the Effects of Microsilica and Nanosilica in Concrete. J. Transp. Res. Board. 2141, 6, 2010.

33. RAOUF E.S., ELKADY H., RAGAB M., BADAWY A.H. Investigation on Concrete Properties for Nano Silica Concrete by using Different Plasticizers. Civil Environ. Res. 6 (9), 36, 2014.

34. RAGHEB A.F. Towards Environmental Profiling for Office Buildings Using Life Cycle Assessment (LCA), University of Michigan. 184, 2011 (Ph.D. thesis)

35. TURK K., KARATAS M. Abrasion resistance and mechanical properties of self-compacting concrete with different dosages of fly ash/silica fume. Indian J. Eng. Mater. S. 18, 49, 2011.

36. PANJEHPOUR M., ALI A.A.A., DEMIRBOGA R. A Review For Characterization of Silica Fume and Its Effects on Concrete Properties. Int. J. Sust. Constr. Eng. Technol. 2 (2), 1, 2011.

37. RAIESS-GHASEMI A.M., PARHIZKAR T., RAMEZANIANPOUR A.A. Influence of Colloidal Nano- $\mathrm{SiO}_{2}$ Addition as Silica Fume Replacement Material in Properties of Concrete. Proceedings Second International Conference on Sustainable Construction 
Materials and Technologies. Universita Ploitecnica delle Marche, Ancona, Italy, 1, 2010.

38. NIU J., RASMUSSEN P.E., HASSAN N.M., VINCENT R. Concentration Distribution and Bioaccessibility of Trace Elements in Nano and Fine Urban Airborne Particulate Matter: Influence of Particle Size. Water Air Soil Poll. 213 (1-4), 211, 2010.

39. WAŁACH D., DYBEŁ P., JASKOWSKA-LEMAŃSKA J. Diagnosis of transport building structures made of highperformance concrete. Logistyka 6, 2014.

40. GRZYBOWSKA A. Wybrane problemy projektowania betonów o niskim stosunku wodno-spoiwowym. Wydawnictwo Uczelniane Uniwersytetu TechnologicznoPrzyrodniczego w Bydgoszczy, 3, 21, 2015 [In Polish].

41. WU H., HUANG B., ASCE M., SHU X., DONG Q. Laboratory Evaluation of Abrasion Resistance of Portland Cement Pervious Concrete. J. Mater. Civ. Eng. 23, 697, 2011.

42. LINCH K.D. Respirable Concrete Dust - Silicosis Hazard in the Construction Industry. J. Occup. Environ. Hyg. 17 (3), 209, 2002

43. HEAL M.R., KUMAR P., HARRISON R.M. Particles, air quality, policy and health. Chem. Soc. Rev. 41, 6606, 2012.

44. KUMAR P., FENNEL P., ROBINS A. Comparison of the behavior of manufactured and other airborne nanoparticles and consequences for prioritising research and regulation activities. J. Nanopart. Res. 12, 1523, 2010.

45. NIU J., RASMUSSEN P.E., HASSAN N.M., VINCENT R. Concentration Distribution and Bioaccessibility of Trace Elements in Nano and Fine Urban Airborne Particulate Matter: Influence of Particle Size. Water Air Soil Poll. 213 (1-4), 211, 2010.

46. KUMAR P., MORAWSKA L. Recycling concrete: An undiscovered source of ultrafine particles. Atmos. Environ. 90, 51, 2014

47. CALVO A.I., ALVES C., CASTRO A., PONT V., VICENTE A.M., FRAILE R. Research on aerosol sources and chemical composition: Past, current and emerging issues. Atmos. Res. 120-121, 1, 2013.

48. KUMAR P., PIRJOLA L., KETZEL M., HARRISON R.M. Nanoparticle emissions from 11 non-vehicle exhaust sources - A review. Atmos. Environ. 67, 252, 2013.

49. PENKAŁA M., OGRODNIK P., ROGULAKOZŁOWSKA W. What we still do not know about road dust. Badania i Rozwój Młodych Naukowców w Polsce. Nauki techniczne i inżynieryjne. Część I. 2018 [In Polish].

50. QIU L., LIU M., WANG J., ZHANG S., FANG C. Source Apportionment of Ambient PM10 in the Urban Area of Longyan City, China: a Comparative Study Based on Chemical Mass Balance Model and Factor Analysis Method. Chem. Res. Chinese Universities. 28 (2), 204, 2012.

51. AZARMI F., KUMAR P., MARSH D., FULLER G. Assessment of the long-term impacts of $\mathrm{PM}_{10}$ and $\mathrm{PM}_{2.5}$ particles from construction works on surrounding areas. Environ. Sci. Processes Impacts. 18, 208, 2016.

52. GUTTIKUNDA S.K., GOEL R., PANT P. Nature of Air Pollution, Emission Sources, and Management in the Indian Cities. Atmos. Environ. 95, 501, 2014.

53. FULLER G.W., GREEN D. The impact of local fugitive from building works and road works on the assessment of the European Union Limit Value. Atmos. Environ. 38, 4993, 2004.

54. GRIGORATOS T., MARTINI G. Brake wear particle emissions: a review. Environ. Sci. Pollut. R. 22, 2491, 2015.
55. GRIGORATOS T., MARTINI G. Non-exhaust traffic related emissions. Brake and tyre wear PM. JRC Science and Policy reports. Literature review. European Commission Joint Research Centre Institute of Energy and Transport, 2014.

56. KUMAR A., KUMAR P., ANANDAN A., FERNANDES T., AYOKO G.A., BISKOS G. Engineered nanomaterials: Knowledge gaps in fate, exposure, toxicity and future directions. J. Nanomater. 130198, 2014.

57. METHNER M., CRAWFORD C., GERACI C. Evaluation of the Potential Airborne Release of Carbon Nanofibers During the Preparation, Grinding, and Cutting of EpoxyBased Nanocomposite Material. J. Occup. Environ. Hyg. 9 (5), 308, 2012.

58. SACHSE S., SILVA F., IRFAN A., ZHU H., PIELICHOWSKI K., LESZCZYNSKA A., BLAZQUEZ M., KAZMINA O., KUZMENKO O., NJUGUNA J. Physical characteristics of nanoparticles emitted during drilling of silica based polyamide 6 nanocomposites. IOP Conference Series: Materials Science and Engineering, $012012,2012$.

59. AZARMI F., KUMAR P. Ambient exposure to coarse and fine particle emissions from building demolition. Atmos. Environ. 137, 62, 2016.

60. NORMOHAMMADI M., KAKOOEI H., OMIDI L., YARI S., ALIMI R. Risk Assessment of Exposure to Silica Dusts in Building Demolition Sites. Saf. Health Work 7 (3), 251, 2016

61. SANTACATALINA M., RECHE C., MINGUILLÓN M.C., ESCRIG A., SANFELIX V., CARRATALÁ A., NICOLÁS J.F., YUBERO E., CRESPO J., ALASTUEY A., MONFORT E., MIRÓ J.V., QUEROL X. Impact of fugitive emissions in ambient PM levels and composition: a case study in Southeast Spain. Sci Total Environ. 408 (21), 4999, 2010.

62. KUMAR P., MULHERON M., SOM C. Release of ultrafine particles from three simulated building processes. J. Nanopart. Res. 14, 771, 2012.

63. ZHANG X., SHEN L., ZHANG L. Life cycle assessment of the air emissions during building construction process: A case study in Hong Kong. Renew. Sust. Energ. Rev. 17, 160, 2013.

64. PENKAŁA M., OGRODNIK P., ROGULAKOZŁOWSKA W. Particulate Matter from the Road Surface Abrasion as a Problem of Non-Exhaust Emission Control. Environments, 5, 9, 2018.

65. BHAGIA L.J. Non-occupational exposure to silica dust. Indian. J. Occup. Environ. Med. 16 (3), 95, 2012.

66. DONG-HEE K., KI-TAE M., JEONG-YOUN K., SEONGWEON C. The risk of hospitalisation for infectious pneumonia in mineral dust exposed industries. Occup. Environ. Med. 68, 2, 2011.

67. AZARMI F., KUMAR P., MULHERON M. The exposure to coarse, fine and ultrafine particle emissions from concrete mixing, drilling and cutting activities. J. Hazard. Mater. 279, 268, 2014.

68. FONT A., BAKER T., MUDWAY I.S., PURDIE E., DUNSTER C., FULLER G.W. Degradation in urban air quality from construction activity and increased traffic arising from a road widening scheme. Sci. Total Environ. 497-498, 123, 2014.

69. BANG K.M., MAZUREK J.M., WOOD J.M., WHITE G.E., HENDRICKS S.A., WESTON A. Silicosis mortality trends and new exposures to respirable crystalline silica United States, 2001-2010. Morb. Mortal. Wkly. Rep. 64 (5), 117, 2015. 
70. MACIEJEWSKA A. Crystalline silica: quartz and cristobalite - respirable fraction. Documentation of proposed values of an occupational exposure limit (OEL). Podstawy i Metody Oceny Środowiska Pracy, 4 (82), 67, 2014 [In Polish].

71. Occupational Exposure Limit Evaluation: Silica, Crystalina Quartz. Toxicology Excellence for Risk Assessment, Cincinnati, Ohio, 2014.

72. LEUNG C.C., YU I.T.S., CHEN W. Silicosis. Lancet, 379 (9830), 2008, 2012.

73. HUNG Y.P., TENG C.J., LIU C.J., HU Y.W., HUNG M.H., TZENG C.H., LIU C.Y., YEH C.M., CHEN T.J., CHIOU T.J. Cancer risk among patients with coal workers' pneumoconiosis in Taiwan: A nationwide population-based study. Int. J. Cancer. 134, 2910, 2014.

74. EHRLICH R.I., MYERS J.E., TE WATER NAUDE J.M., THOMPSON M.L., CHURCHYARD G.J. Lung function loss in relation to silica dust exposure in South African gold miners. Occup. Environ. Med. 68 (2), 96, 2011.

75. STEENLAND K., WARD E. Silica: A lung carcinogen. CA Cancer J. Clin. 64 (1), 63, 2014.

76. National Institute for Occupational Safety and Health (NIOSH): Hazard Review Health effects of occupational exposure to respirable crystalline silica. 129, Cincinnati, 2002.

77. MARKOWITZ G., ROSNER D. Silicosis and the Ongoing Struggle to Protect Workers' Health. Worker Safety Under Siege: Labor, Capital, and the Politics of Workplace Safety in a Deregulated World. 2015.

78. CSAVINA J., FIELD J., TAYLOR M.P., GAO S., LANDÁZURI A., BETTERTON E.A., SÁEZ A.E. A Review on the Importance of Metals and Metalloids in Atmospheric Dust and Aerosol from Mining Operations. Sci. Total Environ. 433, 58, 2012.

79. BORM P.J.A., TRAN L., DONALDSON K. The carcinogenic action of crystalline silica: A review of the evidence supporting secondary inflammation-driven genotoxicity as a principal mechanism. Crit. Rev. Toxicol. 41 (9), 756, 2011.

80. GUHA N., STRAIF K., BENBRAHIM-TALLAA L. The IARC Monographs on the carcinogenicity of crystalline silica. Med. Lav. 102 (4), 310, 2011.

81. EHRLICH C., NOLL G., WUSTERHAUSEN E., KALKOFF W.D., REMUS R., LEHMANN C. Respirable
Crystalline Silica (RCS) emissions from industrial plants - Results from measurement programmes in Germany. Atmos. Environ. 68, 278, 2013.

82. HUGHES J.M., WEILL H., RANDO R.J., SHI R., MCDONALD A.D., MCDONALD J.C. Cohort Mortality Study of North American Industrial Sand Workers. II. Case-referent Analysis of Lung Cancer and Silicosis Deaths. Ann. Occup. Hyg. 45, 201, 2001.

83. SIERRA-CALDERON D.D., SEVERICHE-SIERRA C.A., BEDOYA-MARRUGO E.A., MEZA-ALEMAN M.deJ., ESPINOSA-FUENTES E.A. Silice in the Sandblasting Industry: a review from Occupational Safety and Health. J. Appl. Eng. Res. 13 (8), 6274, 2018.

84. ADGATE J.L., GOLDSTEIN B.D., MCKENZIE L.M. Potential Public Health Hazards, Exposures and Health Effects from Unconventional Natural Gas Development. Environ. Sci. Technol. 48, 8307, 2014.

85. CARBONARI A., NATICCHIA B., VACCARINI M., NOVEMBRI G. Pervasive Sensor Network For Real Time Environmental Monitoring In Construction Sites. Proceedings of the International Symposium on Automation and Robotics in Construction (ISARC). Vilnius Gediminas Technical University, Department of Construction Economics \& Property, 30, 1, 2013.

86. IMANI M., HEIDARI H., RAHIMIFARD H., MAHDINIA M., HASELI F., AZIZI F., MOKHTARI S. Assessment of Occupational Exposure to Silica Dust and Respiratory Effects in Exposed Workers in one of the Ceramic Products Industry. Sci. J. 36 (4), 1893, 2015.

87. SHAH D.A. Evaluating Real-Time Air Monitoring System of $\mathrm{PM}_{10}$ Emission from Highway Construction Work Zones. Texas A\&M University - Kingsville, 10638512, 2016.

88. ROGULA-KOZŁOWSKA W., MAJEWSKI G., CZECHOWSKI P.O. The size distribution and origin of elements bound to ambient particles: A case study of a Polish urban area. Environ. Monit. Assess. 187 (5), 240, 2015.

89. ROGULA-KOZŁOWSKA W. Size-segregated urban particulate matter: mass closure, chemical composition, and primary and secondary matter content. Air Qual. Atmosph. Health 9 (5), 533, 2016. 
